gravest problems that man has to grapple with; and secondly, in that it has more or less distinct reference to a past of which the present is but an outcome and a development.

C. Lloyd MORGAN.

\section{HERMANN HELLRIEGEL}

PROF. HERMANN HELLRIEGEL, whose death took place at Bernburg, Anhalt, on September 24 last, was born at Pegau, Saxony, on October 2I, I83I, so that he was within a month of completing his sixtyfourth year. His life, on the whole, was uneventful, for he devoted himself with studious zeal almost entirely to investigations, both chemical and physiological, into the phenomena of plant nutrition. One of his earliest official posts was that of Director of the Agricultural Experiment Station at Dahme, in Brandenburg, which was founded in 1857 by an association of agriculturists in Jüterbog-Rückenwalder. During his tenure of this post he studied experimentally the alimentary needs of certain plants which are cultivated as field crops, notably cereals, potatoes, and sugar-beet, his method involving the use of sterilised soil, both by itself and with the addition of various chemical salts. His physiological inquiries embraced observations on the growth and development of roots, on the quantity of water used in the growth and maturation of field crops, and on the minimum amounts of nitrogen, phosphoric acid, potash, and other ingredients required by plants. Supplemented by observations on crops grown in the open field, these investigations led Hellriegel to conclusions of great practical importance, notably in connection with sugar-beet, a crop which Germany grows more extensively than any other European country, its annual average area for the last twelve years having been 800,000 acres, or more than onefourth of the entire European acreage.

It was with no little regret that in 1873 Hellriegel gave up his directorship at Dahme, though for a post with greater emoluments. But his capacity as an investigator had made its mark, and when in 1882 the Verein für Zucker-Industrie, in co-operation with the Government of the Duchy of Anhalt, established an experimental station at Bernburg, for the special investigation of problems bearing upon the cultivation of sugar-beet, it was felt that Hellriegel possessed special and peculiar claims to the directorship, which was accordingly offered to him. He accepted with avidity a post which enabled him again to devote his time and energy solely to those investigations into plantlife, which had previously exercised upon him so strong a fascination. The station at Bernburg is admirably equipped, and Hellriegel found himself in a position to at once resume his inquiries into the nutrition of leguminous plants, a subject that had previously received his attention at Dahme. It was here that after a dozen years' work he, in collaboration with Dr. Wilfarth, made the great discovery with which his name will ever be inseparably associated, namely, the capacity of leguminous (or at least of papilionaceous) plants to take up, or fix, through the agency of the micro-organisms of their root-nodules, the free or uncombined nitrogen of the atmosphere.

The intimation - the revolutionary announcementof this startling discovery was made on September 20 , 1886 , in a communication to the Naturforscher Versammlung, held at Berlin, and over the agricultural chemistry section of which Dr. (now Sir Henry) Gilbert happened to be presiding - a coincidence of exceptional interest in view of the circumstance that Sir Henry Gilbert was one of the joint authors of the celebrated memoir by Lawes, Gilbert, and Pugh, "On the sources of the nitrogen of vegetation, with special reference to the question whether plants assimilate free or uncombined nitrogen" (Phil. Trans. I861), which, at the time of its appearance, and for long after, was regarded as setting at rest the question as to the capacity of plants to assimilate the free nitrogen of the atmosphere, and of confirming upon this point the negative results previously obtained by Boussingault. Hellriegel's momentous discovery furnished an explanation of the long-known fact that a clover-crop leaves the soil richer in nitrogen than it finds it, and is therefore a suitable crop to precede the wheat-crop in a rotation, clover being-as we now understand through Hellriegel's discovery-a nitrogen-accumulating plant, and wheat a nitrogen-consuming one. Indeed, the fact itself is a very old one, for it was observed by the farmers of the Roman Republic that beans, lupins, vetches, and other plants belonging to the sub-order Papilionaceæ, as now defined, rendered the soil "more fruitful" for the crops that followed. But nearly 2000 years elapsed from the time when Varro recorded this, to that when Hellriegel, a brief nine years ago, supplied the explanation. It in no way detracts from the value and significance of the discovery that Hellriegel and Wilfarth should have happened upon it in the course of investigations which were really directed to quite a different object. Those who devote their lives to research are not unaware that gems, hitherto unseen, may sometimes be picked up on the wayside.

We have spoken of Hellriegel's discovery as revolutionary, and it certainly upset a long-cherished belief. The opposition which his announcement received at the outset was a testimony to its importance. Subsequent research, both in Europe and in North America, has, however, only strengthened the position which Hellriegel took up, whilst it has suggested new lines of investigation for which there will probably be no lack of workers. Bréal, Frank, Hiltner, Lawes and Gilbert, Schlosing fils and Laurent, are but a few of the investigators who have proved the accuracy of the discovery made at Bernburg. In recognition of his work, Hellriegel was elected an honorary member of the Royal Agricultural Society of England, a rare distinction, which he enjoyed in common with such continental workers as Pasteur, Fleischmann, and Chauveau. In France his merits were recognised by his election as a foreign associate of the Société nationale d'Agriculture, and as a Correspondant of the Academy of Sciences.

\section{NOTES}

The German committee for the exploration of the South Polar regions met at Berlin on Sunday, and decided to send two vessels southwards from Kerguelen Island, leaving full liberty of action to the leaders. The total sum to be allotted for the expedition, which is to last three years, has been fixed at 950,000 marks $(£ 47,500)$.

Chicago University continues to be the recipient of Fortune's favours. Mr. John D. Rockefeller has (says the New York correspondent of the Daily Chronicle) added $£ 200,000$ to his previous gift of $£ 800,000$ for the endowment of the Chicago University. He promises $£ 400,000$ more if any one else will subscribe a like sum. When will the day come for such generous gifts to education and research in England?

The Municipal Council of Arbois, the birthplace of Pasteur, has decided to erect a statue to his memory, and also to call the municipal college the Pasteur College.

M. BERTHELOT, the distinguished chemist, has been appointed Minister of Foreign Affairs in the new French Cabinet. He was Minister of Education in the Cabinet of I886-87.

IT is reported that the Paris Municipality have granted $£ 800$ to the Salpetrière Hospital for the erection of new buildings in which to treat nervous and mental affections by electricity. NO. 358 , VOL. 53] 